Article

\title{
Constructing Silence: Processes of Journalistic (Self-)Censorship during Memoranda in Greece, Cyprus, and Spain
}

\author{
Sofia Iordanidou ${ }^{1, *}$, Emmanouil Takas $^{2}$, Leonidas Vatikiotis ${ }^{2}$ and Pedro García ${ }^{3}$ \\ 1 Open University of Cyprus, 1045 Nicosia, Cyprus; E-Mail: sofia.iordanidou@ouc.ac.cy \\ ${ }^{2}$ Advanced Media Institute, 15234 Athens, Greece; E-Mails: manostakas@gmail.com (E.M.), \\ leonidas.vatikiotis@gmail.com (L.V.) \\ 3 International University of La Rioja, 28022 Madrid, Spain; E-Mail: pedro.garcia@unir.net \\ * Corresponding author
}

Submitted: 12 November 2019 | Accepted: 24 December 2019 | Published: 25 February 2020

\begin{abstract}
What are to be considered as threats against journalism? Whereas the literature on safety of journalists mainly discusses threats as part of armed conflicts, this article studies how other kinds of conflicts such as economic strangulation and the viability threat represent threats against journalists' work and safety. It argues that acts of intimidation directed against journalists represent an attack on democracy itself as they have the effect of limiting the freedom of expression. The aim of this study is to explore how journalists operate in such a conflict and under such uncertainty, as an implication of (political) pressure caused by the politics of Memoranda in Greece, Cyprus, and Spain. The comparative analysis focuses on possible changes in the processes of message construction and in the journalistic practices of the participants, exploring if, how, and to what extent these changes were imposed to journalists directly or indirectly.
\end{abstract}

\section{Keywords}

European South; journalists; memorandum; safety; self-censorship; silence

\section{Issue}

This article is part of the issue "Rethinking Safety of Journalists" edited by Kristin Skare Orgeret (Oslo Metropolitan University, Norway) and William Tayeebwa (University of Makerere, Uganda).

(C) 2020 by the authors; licensee Cogitatio (Lisbon, Portugal). This article is licensed under a Creative Commons Attribution 4.0 International License (CC BY).

\section{Introduction}

What makes journalism a "safe" profession? Does a threat to life, as for instance in an armed conflict, constitute a condition that can lead to the impoverishment of the journalistic content or are there other kinds of "conflicts," such as economic strangulation and the threat to viability, that can intervene in the function of journalism as monitoring? The aim of this research is to explore to which extent the Memoranda in three countries of the European South-Greece, Cyprus, and Spainfunctioned as "pressure points" on the journalistic content or to what extent media suppression is an indicator of broader powers of corruption, political control and anti-democratic practices (Hanitzsch \& Vos, 2018; Wolfgang, Vos \& Kelling, 2019).

\section{The Safety of Journalists}

According to the Committee to Protect Journalists, since 1992, 855 journalists lost their lives. In 2018, in particular, 54 journalists were killed or murdered in the battlefields and 251 were imprisoned. During the decade 2007-2017, 800 media professionals were killed in total; during 2015-2017, 59\% of them lost their lives in battlefields, with a $95 \%$ of them being local correspondents (Carlsson \& Pöyhtäri, 2017). In addition, new media have undoubtedly played an important role in the development of political movements, e.g., in Tunisia and Egypt (Khondker, 2011, p. 678), facilitating and sometimes enhancing the work of journalists (Cottle, 2011) who had been excluded from the regimes. Political volatility arising from such disturbances leads local regimes, who 
seek to maintain their power, to actions that afflict independent journalism and the true mission of the media. Journalists are murdered not only to provoke a shock, but also as a means of intimidation. Murder has thus become an effective lever for the activity of terrorist-militia pressure groups, but for some regimes as well, who use it as a means of reducing the control applied to them. Apart from that, technological progress, which can be a blessing for facilitating a professional, can be a curse at the same time, because it makes tracing or even targeting the action or the position of a journalist easier.

Another important source of threat for journalists derives from organized crime, especially in certain countries of Asia, Central and South America, such as Mexico and Colombia, which appear as areas of high risk. Carlsson and Pöyhtäri (2017, p. 12) note that the majority of victims do not come from countries in war, but are involved in the disclosure of information concerning drug trafficking, human rights violations, and corruption.

Even though the "physical" safety of journalists has been widely discussed, less attention has been given to their psychological safety. Psychological safety has been defined as "individuals' perceptions related to the degree of interpersonal threat in their work environment" (Nembhard \& Edmondson, 2012, p. 2); as the feeling of being able to "show and employ one's self without fear of negative consequences to self-image, status or career" (Kahn, 1990, p. 703); or a feeling that provides a sustainable psychological path to high performance, even in uncertain environments (Edmondson, 2008). Psychological safety has a positive effect on collaboration (Gratton \& Erickson, 2007), experimentation (Madsen \& Desai, 2010), on organizational learning and performance (Choo, Linderman, \& Schroeder, 2007; Nembhard \& Tucker, 2011), self-confidence in the workplace (Edmondson, 1999), while increasing the propensity to share one's knowledge in psychologically safe places (Siemsen, Roth, Balasubramanian, \& Anand, 2009). In addition, increased insecurity, especially derived from increasing unemployment rates and perceived job vulnerability, leads to high psychosocial work stress and burnout (Tsai \& Chan, 2011). The international crisis that started in 2008 has highlighted the need to focus more on "economic stress" as a crucial factor of psychological insecurity that affects perceived vulnerability, employees' well-being, job satisfaction and performance (Bond \& Bunce, 2001; Chalofsky, 2003; Karasek, 2008). Even though scholars have long recognized the threat of job insecurity, unemployment, and underemployment to the psychological safety of employees, less attention has been given on economic stress such as employees' current financial status, their worries on financial issues and the multi-level effects of economic stressors on different socioeconomic levels of analysis (Probst, 2005). Especially in these times of crisis, organizations have been driven by an economic rationalist calculus, while the costly consequences of compromised worker psychological health driven by economic stress have been largely ignored (Dollard, 2007; Johnson, 2008). Even though "economic stress" as a product of the economic crisis has been found to generally have an impact on general stress, anxiety and depression (Viseu et al., 2018), on polarization and "middle class squeeze" (Whelan, Russell, \& Maître, 2016) and on personal and social coping resources (Bartholomae \& Fox, 2017), little attention has been given on the effects of economic stress on the journalistic practice, especially in the countries of the "European South" and in particular on the perceptions and experiences of the journalists who were expected to operate under the political and economic pressures emanating from the logic of the Memoranda.

In Cyprus, Greece, and Spain, that this article examines, the new working environment that has emerged due to the economic crisis has outplaced the experienced and more highly-paid professionals, resulting in phenomena of insufficient advocacy of the professional relations code and even of the journalist code of conduct, therefore leading to the "pauperization" of also the younger, training journalists. This lack of job security constitutes a source of corruption and self-censorship for journalists, causing an internal, self-fueled crisis. In the case of Cyprus, the press, while covering the demonstrations outside the House of Parliament during the deliberations on Eurogroup decisions, inclined to the deconstruction of the demonstrators and of their demands, legitimizing policies from above (Spyridou, 2015). In general, the autonomy of journalists in Cyprus is at risk because of their dependency on the government, commercial interests and, more recently, job insecurity (Milioni, Spyridou, \& Koumis, 2017).

Similar phenomena emerged in Greece as well, where the crisis, up to a certain point, was subserved by the stance of the media (Nikolaidis, 2017). Strict fiscal adjustment, dismissals in both private and public sectors, reduction in advertisements on the press, etc., made lots of journalists accept serious curtailments on their wages, work under the abiding monitoring of the editorial board, and enter a form of self-censorship as they were trying to strike a balance between the correlated systems of politics, economy and media, in order to protect their job (losifidis \& Boucas, 2015). Additionally, journals and magazines sales figures decreased by $50 \%$ between 2012 and 2017 (Hellenic Statistical Authority, 2018). Although the life of journalists in Greece, Cyprus, and Spain is not directly threatened, according to the "Reporters without Borders" a new, emerging, form of economic threat seems to have advanced upon them; at least, this is shown in the interviews taken in the context of this research. Apparently, this is not irrelevant to the new state of affairs that late neoliberalism built up in the countries of the European South, which-in the case of Cyprus for example-as noted by Vogiatzoglou (2016), victimized the island, even though two years after the loan agreement some indices shifted towards the correct direction. 


\section{Greece, Cyprus, Spain: Alliances in Respect to Memoranda and Economic Deficiencies}

On August 2018, the termination of the third economic adjustment program for Greece, which accompanied the third loan, put an end to the most economically turbulent period of postwar Greece. The crisis, before derailing in terms of fiscal policy, started in 2008 as a circular recession. In 2010, the Greek government and the creditors proposed choices to eliminate the risk of defaulting on payments, which are to blame for the extremity of the crisis. Greece, which was the first country of the European South to be subjected to the Memorandum mechanism in April 2010, received in total $€ 288.7$ billion: 256.6 from European sources and 32.1 from the International Monetary Fund (IMF; European Stability Mechanism, 2018).

Spain acceded to the Memorandum regime in July 2012, for a period of 18 months, and the Program ended in January 2014. The agreement with the EU stipulated that Spain would borrow up to $€ 100$ billion, with the exclusive aim of rescuing its banks (European Commission, 2012). Finally, it deployed $€ 38,9$ billion for the recapitalization of its commercial banks and $€ 2.5$ billion as capital injection for the establishment of Sareb, which according to the Irish model operated as a "bad bank" absorbing the toxic assets of the four nationalized banks (BFA Banca, Catalunya Bank, Banco Gallego, and Banco de Valencia). The metastasis of the deep structural crisis of 2008 in Spain was triggered by the property bubble of the preceding decade, which in turn was the result of irresponsible lending by the banks. Albeit the responsibility of the banks, the condition for the financing of Spain, in the framework of an internal devaluation policy (as it also happened in Greece), was wage reduction and other measures that deteriorated the position of lowerincome classes.
Cyprus was the last country to join the rescue mechanism. The Cypriot crisis mostly resembled the Irish and the Spanish ones, because it originated from the banks. In 2011, the ratio of bank assets to Gross Domestic Product (GDP) reached $896 \%$. In 2012, the private debt (of households and businesses) reached $288 \%$ of the GDP (Kosmas, 2019). The purchase of Greek bonds on behalf of the Cypriot banks, which were later subjected to a "haircut" following the decision of the European Commission in the context of the 2012 restructuring-without provision for any compensation, although Cyprus was an EU membertransferred the crisis from Greece to Cyprus. Apart from the already known terms of funding, such as wage reductions, privatizations, etc., what was also included in the case of Cyprus was the "haircut" to deposits over $€ 100,000$. It was the first time that such a measure was implemented in the EU. Cyprus was subsumed under the rescue mechanism in March 2013; it borrowed $€ 10$ billion and exited in March 2016 (European Commission, 2013).

The inclusion of the above three countries in the regime of limited sovereignty that the Memoranda imposed, strengthened the links among them. There are three prevailing similarities: Firstly, in all three countries, the public debt is much higher after their "rescue," contrary to the level it was before the crisis, as it is apparent from Figure 1. Consequently, they are more susceptible to an abrupt shift of the economic cycle.

Secondly, all three countries are under a surveillance regime, as stipulated by the regulation $472 / 2013$ of the European Parliament and Council (European Parliament, 2013). As a result, economic policy (everything concerning public spending, banking sector, labor market, social policy, etc.) comes under the rigorous monitoring of European institutions.

Thirdly, social welfare indices have yet to return to their pre-crisis levels. In Greece, unemployment in 2019

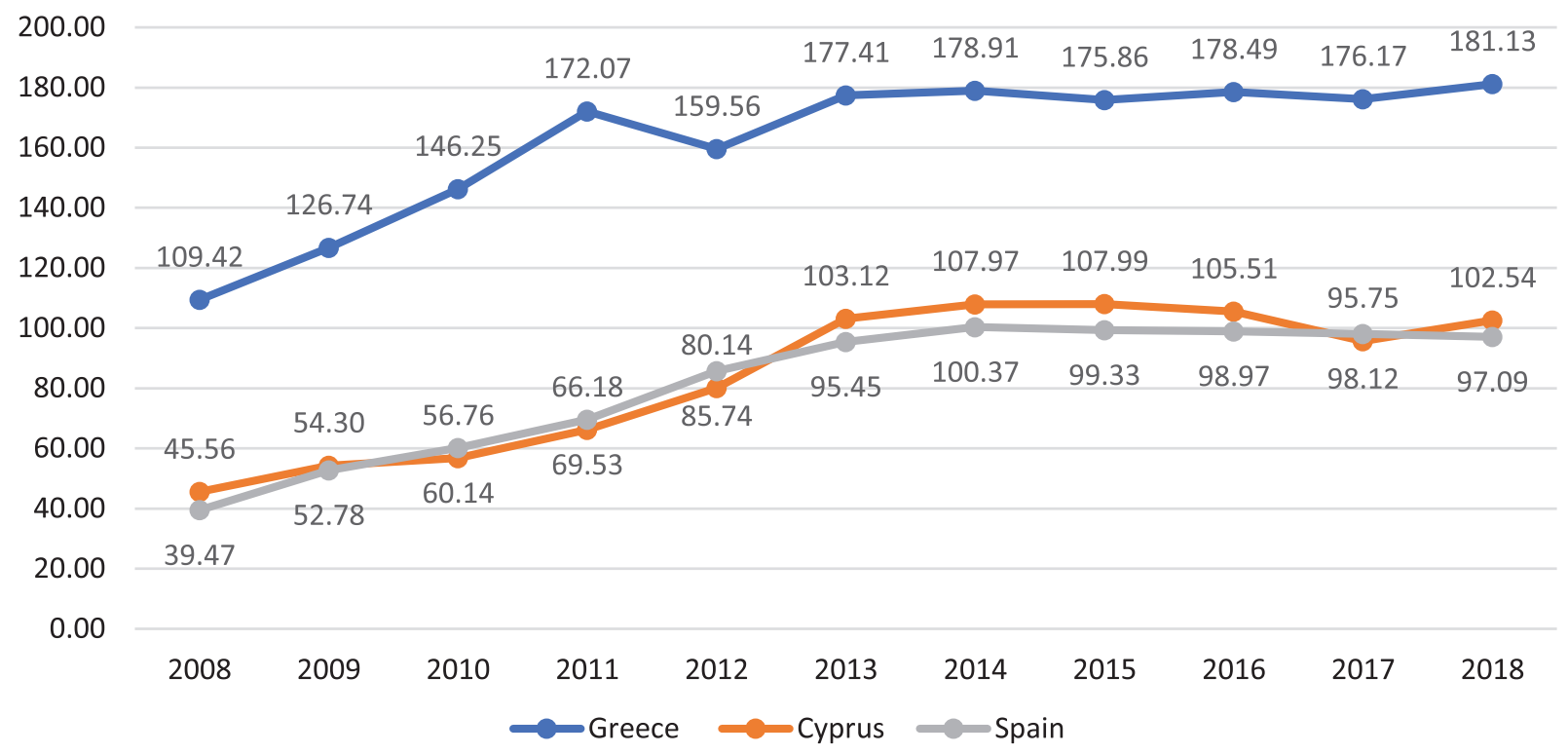

Figure 1. Public debt as a ratio of GDP. Source: European Commission's Directorate General for Economic and Financial Affairs (2019). 
is double than in 2008 , wages and pensions are by $40 \%$ lower, collective bargaining has been abolished by law, and Greece is the only member state of the EU where the minimum wage is decided by state law. In Spain, in 2018, the unemployment rate was higher than in 2008 (15.3\% instead of $11.3 \%$ ), although during that decade wages decreased and the labor market became more flexible, e.g., in 2017, $90 \%$ of jobs were temporary and one third of them lasted less than a week (Alderman, 2019). Furthermore, Spain still had the highest school dropout rate in the EU: 19.9\% in 2015 (Villanueva \& Vega, 2019). In Cyprus, unemployment in 2018 was more than double in comparison to 2008 (8.4\% from 3.7\%); in the meantime, a broad program of first-residence auctions is imminent, which will deteriorate the terms of housing for thousands of Cypriots, but will enable the banks to purge their portfolios.

Some common characteristics that run deeper can also be traced in the roots of the economic crisis. No matter what form it took (public debt and banking crisis), it was a crisis that challenged and shook the dominant economic model, that of neoliberalism, as it is demonstrated in financialization and globalization (Duménil \& Lévy, 2011). It deteriorated as well, due to the participation of these three countries in the Eurozone, which translated into inability to recourse to traditional measures of monetary policymaking for the management of the crisis (Lapavitsas et al., 2012).

In that context, journalists were in the forefront of pressure, not only having to manage an extended, stressful, and unpleasant situation, but also having to analyze it, sometimes even serve it. On the one hand, they had to cover suicides or school closures and, on the other, cuts on wages and continuing lay-offs, which were an everyday phenomenon. The contrast boiled up due to the fact that economic volatility made the owners and managers of the media more submissive to political and economic authority, in order to ensure their survival. That process raised issues for the "safety" of journalists, not only as a result of a threat to their lives, but also as a psychological after-effect of the extended insecurity climate.

\section{Media Landscapes in Greece, Cyprus, and Spain}

In Greece, 12 daily newspapers and 20 Sunday papers are in circulation, and six nationwide private television channels broadcast. Newspaper circulation in 2018 amounted to 54.2 million papers from 248.5 million in 2007 , and magazine circulation amounted to 20.6 million, from 111.4 in 2007-one year before the crisis hit. Media ownership in Greece is characterized by a very high degree of concentration, indicative of very low levels of media pluralism, a concept that embraces aspects such as diversity in the ownership of media and variety in the sources of information (Leandros, 2010). Circulation figures are topped by the newspapers that belong to media groups owning television channels, radio stations, and websites (horizontal ownership) as well, or even a press distribu- tion agency (vertical ownership). At the same time, diagonal ownership flourishes as well, as the most powerful owners of media groups are also ship-owners or conduct business in the refining and trade of crude oil, construction, tourism, and other industries. The press in Greece is politically active in an intense way, identifying with political parties (Papathanasopoulos, 2005); it comes as no surprise that investigative journalism has significantly shrunk, due to the deep economic crisis.

The Cypriot press shows a remarkable selling decline in both newspaper and magazine. The readership index of the first quarters of 2016 to 2019 is reduced by $4 \%$ (from $14.4 \%$ to $10.5 \%$ ), while the GDP of Cyprus is increasing. Four daily and two Sunday political newspapers are printed in Cyprus. One of them (Haravgi) belongs to the Communist Party, while the rest of them (Fileleftheros, Politis, Alitheia, Simerini, and Kathimerini) belong to media groups that also manage other media (radio, magazines, television, websites), a practice gradually abandoned in Europe. It is remarkable that most newspapers were founded with the occupation of Cyprus featuring central on their agendas. Overall, Cyprus seems to rather have freedom of expression and media pluralism, since constitutional and legal provisions protect citizens' rights connected to the freedom of expression (Christophorou \& Spyridou, 2017).

Mass media in Spain are characterized by concentration in large private groups, among which Atresmedia, Mediaset España, Prisa and Vocento stand out-we could add others of a more regional scope, such as Grupo Godó, Grupo Zeta, Corporación Voz de Galicia, Editorial Prensa Ibérica, Grupo Joly, Grupo Heraldo, etc. Recently, hundreds of new independent digital projects have been added. The four large corporations are publicly traded on the stock exchange. And their shareholders include large financial corporations, banks, and multinationals. Despite this, the greatest influence on information is politics. The private market is influenced through subsidies and the granting of institutional advertising. This generates controversy, since it leads to public institutions interfering with the editorial lines of the media. Ideologically, Spanish media are divided into two clear axes which should not be ignored. The first, horizontal, has to do with a positioning between the political left and right. The second one, vertical, has to do with the promotion of a unified country versus the promotion of nationalism (Salaverría \& Beceiredo, 2018).

\section{Methodology}

\subsection{Interpretative Phenomenological Analysis and Journalists}

The journalistic profession, and especially the "safety" (physical or psychological) of the journalists, has been approached quantitatively (e.g., Browne, Evangeli, \& Greenberg, 2012; Feinstein \& Starr, 2015; Levaot \& Mark Sinyor MSc, 2013) with less studies focusing on the quali- 
tative and in-depth understanding of the journalists' psychological processes and practices generated by feelings of insecurity. Interpretative Phenomenological Analysis (IPA) is a distinctive approach to qualitative research, based on the methodological approaches of Smith (1996) and Smith, Jarman, and Osborn (1999) and on the assumption that individuals do not passively perceive of an "objective" reality, but they interpret and formulate their (personal) social reality from their own biographical experiences. The aim of the IPA is to explore in depth the processes of experience, understanding, perceptions and views (Reid, Flowers, \& Larkin, 2005). As it is "phenomenological," this approach acknowledges the dual facets of the method (both the participants' and the researchers') and the joint reflections that form the analytic account produced (Osborn \& Smith, 1998).

By applying IPA in this study, we aim to provide an in-depth understanding of how the participants experienced the politics of the Memoranda in each country examined. The aim is not to create a representative study, but rather to understand the way in which the Memoranda affected the journalistic practice of the participants.

\subsection{Participants}

All data were derived from 35 semi-structured interviews (Greece, $\mathrm{n}=14$; Cyprus, $\mathrm{n}=9$; and Spain, $n=12$ ). Participants were journalists working in traditional and new media in each country at the time of the Memoranda and had over 15 years of experience in traditional or traditional and new media. Participant information is provided in Table 1.

\subsection{Procedure}

The qualitative data were obtained through semistructured interviews, which lasted between 30 and 60 minutes. All interviews were recorded and transcribed. All participants were given an information sheet regarding the present study, informing them on issues such as assurance of anonymity, the right to withdraw, the interview process, and the goals of the study. After having read the information sheet, participants were provided with a consent form for the study. After signing the consent form, participants were assigned a code with the abbreviation of the country (ParticipantGR01, ParticipantCY02, ParticipantSP03, etc.), the interview began, and participants were paid for their time.
The interviews were conducted with the discussion focusing on the following four focal areas: First, the participant's journalistic experience; the questions were focused on the participants' experiences regarding the journalistic profession and how they were involved in journalism even before the Memoranda.

Second, how the influence of the Memoranda was understood by society and how it affected journalism in general, according to the participants' experiences and views, as well as the influence of the Memoranda on the participants' journalistic practice. This area included questions regarding the recognition of the main influence of the Memoranda in the participants' countries and the idea of "silence," i.e., how and to what extent the influence affected the content they produced.

Third, the understanding of the "pressure points," namely the exact "loci of pressure" that the participants recognized, which interfered with their practice. The "intensity" of this "pressure" was also qualitatively examined to provide a more general comparative overview of the perceived pressure.

Fourth, the approach of using semi-structured interviews enabled participants to discuss issues that were of primary concern to themselves. As such, this study does not provide "generalized" results, but it examines in depth the participants' perceptions regarding the effect of the Memoranda in Greece, Cyprus, and Spain.

\subsection{Analysis}

All materials from the interviews were analyzed using IPA (Smith, Jarman, \& Osborn, 1999), aiming to create concise and mutually exclusive themes that are significant within the transcribed material. Each interview was analyzed individually, and the relevant items and emerging themes were recognized. Connections between the themes led to their ordering in preliminary lists. Master themes for each interview were created and, upon completion, all master themes from all interviews were assembled in greater categories, the superordinate themes. All themes were represented verbatim from the original material and the external reliability of the analysis was ensured by an external, independent researcher with extended experience in IPA methodology.

\section{Results}

Two super-ordinate themes emerged from the analysis: (i) Influences of the Memoranda; and (ii) pressure

Table 1. Participant information.

\begin{tabular}{llll}
\hline Information/Country & Greece $(n=14)$ & Cyprus $(n=9)$ & Spain $(n=12)$ \\
\hline Gender & Male: 9 & Male: 7 & Male: 7 \\
& Female: 5 & Female: 2 & Female: 5 \\
Age range & $37-58$ & $44-61$ & $39-59$ \\
Mean age & 49 & 51 & 47 \\
\hline
\end{tabular}


points. The thematic structure of the analysis is displayed in Table 2.

\subsection{Influences of the Memoranda}

The first super-ordinate theme of "Influences of the Memoranda" emerged from the answers of the participants regarding how and to what extent the logic of Memoranda affected the journalistic practice at two levels. Firstly, the perception of the participants regarding how the Memoranda affected the "Others" (Table 2, Code 1.1.), and secondly, how the Memoranda affected the "Self" (Table 2, Code 1.2.), that is the participants themselves on their profession. Regarding the first master theme, two sub-categories emerged: financial influences (Table 2, Code 1.1.1.), and influences on journalistic practice (Table 2, Code 1.1.2.). The financial influences mentioned were predominantly negative: "Look, the Memoranda brought redundancies and insecurity everywhere. You could see and feel that financially everything has changed" (ParticipantGR02); "The most important issue is that the financial crisis opened the door to the financial loci to have more influence on society than politicians did" (ParticipantCY06); "In Spain there was a close and complex relation between the financial system and media groups. The Memorandum affected a lot the relationship with the banking system" (ParticipantSP03). From the qualitative analysis, all participants in all countries recognized that the Memoranda had a negative impact on the wider economy in general and the journalistic field in particular. The negative impacts were not only measured financially (cut-offs, lay-offs) but also psychologically, in terms of creating feelings of insecurity.

Influences on journalistic practices (Table 2, Code 1.1.2.) emerged from the participants' replies regarding the effects of the Memoranda on the journalistic practice itself: "The Memorandum changed the whole journalistic landscape. The political system, the IMF, Europe, everyone involved wanted to change the way journalism worked" (ParticipantGR08); "Less recruitments meant lower quality. Today those who say that they are journalists are of lower quality than the older ones, they are cheap labor" (ParticipantCY06). Even though Greek and Cypriot participants all recognized, to a smaller or larger extent, the financial impact of the Memoranda on the journalistic practice, participants from Spain acknowledged less direct impact, though acknowledging some indirect pressure: "There might have been influences on the companies for example, but I don't think that the media have been that affected" (ParticipantSP07). The results in this sub-category point to the influence of the Memoranda regarding the notion of "qualitative journalism." Abramson (2010) recognizes the challenges that journalism faced, to acknowledge the direct and indirect influences especially in times of crisis, and argues that financial cut-downs and lay-offs have a negative impact on the quality of journalism, given also the transformative era of today's media (McNair, 2013).

Influences on the "Self" (Table 2, Code 1.2.) emerged from the answers of the participants in respect to the impact that such influences had on their personal journalistic practice, implying processes of self-censorship: "Well, self-censorship was all around, especially if you worked for a Medium that had a specific 'line.' In case you went against that line, you would be marginalized and lose your job" (ParticipantGR04); "There was generally a heavy 'climate.' I think it lasted just for a while. It was a shock, but I think we soon found our pace" (ParticipantCY05). As ParticipantSP02 remarks:

In my opinion, I would say insecurity leads to selfcensorship. The reasons vary, but I think that, a lot of times, are more related to the prejudices of the journalists, the fear of losing their jobs or the concern about the crisis and its consequences on the media where they work.

Interestingly enough, only the Greek journalists recognized the process of self-censorship directly. Cypriot and Spanish participants mentioned vaguely a connection between financial insecurity and self-censorship but none of them stated directly that they personally have been involved of some kind of self-censorship, despite the fact that they all acknowledged the role of the financial crisis and the effect of the editorial "line" on the construction of the journalistic message. This finding could be interpreted by what Hayes, Scheufele, and Huge, (2006) call "non-participation as self-censorship," namely the fact that journalists avoided to enter a pro- or an antiMemorandum attitude in order to feel secure in their working environments.

Overall, the Greek participants acknowledged intense influence both at the larger societal and financial level and at the personal level, that is their own journal-

Table 2. Compositional structure of IPA themes.

\begin{tabular}{lllll}
\hline Thematic Level & Code & Theme One & Code & Theme Two \\
\hline Super-ordinate theme & 1 & Influences of the Memoranda & 2 & Pressure Points \\
Master themes & 1.1. & Influences on Others & 2.1. & External Factors \\
& 1.2 & Influences on Self & 2.2. & Internal Factors \\
Sub-categories & 1.1 .1$. & Financial Influences & 2.1 .1$. & Troika \\
& 1.1 .2$. & Influences on journalistic practice & 2.2 .1$. & Government \\
& 1.2 .1$. & Self-Censorship & 2.2 .2$. & Media Owners \\
& & & 2.2 .3$. & Banks \\
\hline
\end{tabular}


istic practice. Cypriot participants mentioned a relatively mild influence of the Memorandum in most areas and the Spanish participants in their majority did not recognize any direct influence of the Memorandum on their profession and said that, if there was some influence, it was very mild and abstract.

\subsection{Pressure Points}

The super-ordinate theme "Pressure points" emerged from the participants' replies regarding how and to what extent they felt "pressure" on the journalistic practice. Two master themes emerged: External Factors (Table 2, Code 2.1.), and Internal Factors (Table 2, Code 2.2.). The distinction between "external" and "internal" factors was constructed based on the country, namely whether the "pressure points" were found "outside" their country (e.g., Europe, Troika) or "inside" their country (e.g., government).

Regarding the external factors, from the replies, "Troika" (Table 2, Code 2.1.1.) emerged as a locus of pressure:

The Troika at first used specific platforms, like in Ireland, for delivering information to journalists. Soon enough, the Troika employed companies for strategic communication. At first, these companies were used just to organize meetings, after a while they distributed the 'non-papers.' (ParticipantGR03)

Also, as ParticipantSP06 stated: "Sometimes, informative meetings have been arranged by the European Commission for journalists. The aim was to explain and to discuss 'off the record' specific movements of the Troika. Especially during the most difficult moments of the crisis with Greece." The Cypriot participants did not feel there was an official pressure by the Troika to the journalists. The interference of the Troika as a direct "pressure point" was mostly and most intensely present in the replies of the Greek journalists. Greek participants acknowledged that "there was a 'core' of journalists, to whom specific directives were given" (ParticipantGR02); that the Troika unofficially organized "Greek-German friendship seminars as an integral part of journalists 'proselytism"' (ParticipantGR13). Interestingly, the Spanish participants recognized the interference of the Troika to Spain as a result of the Greek crisis and as a way to "prevent" the "Greek paradigm" to affect other countries under the logic of the Memoranda.

"Government" (Table 2, Code 2.2.1.) emerged from the replies of the participants regarding how and to what extent government officials interfered directly or indirectly with the construction of the journalistic message:

Look, the most intense interference was during the Papadimos era. It was direct and lasted until the next government. I was told that I had to start my TV show playing videos that had a positive effect on the market, silly things, for example to show how the Americans threw teddy bears with hearts during a rugby game..... Of course, I refused. (ParticipantGR11)

Additionally, "the big issue in journalism is that one has to have sources. And these sources decide how close you will get to them. So, if you wrote something against them, you automatically lost your sources" (ParticipantCY09); "the point is that, in Spain, media, especially the press, but also television, depend on the government, in one way or another. For example, Spanish media groups, for the large part, depend on the licenses which are provided" (ParticipantSP01). Greek participants in general acknowledged a more direct interference of government officials to the journalistic practice, while Cypriot and Spanish participants mostly referred to the "proximity to the source" issue. Greek participants also acknowledged the indirect interference: "If you were not with the government, you were not a patriot. I mean the Memorandum was the patriotic thing to do. If you did not support it, then the government cut you off from the information" (ParticipantGR02). Additionally, Greek participants mentioned direct interference of the Government to the journalistic practice: "People came to the office and said to the chief editor that he [name of the politician] wants you to write this" (ParticipantGR06). Political interference to journalism has been widely discussed (e.g., Milojević \& Krstić, 2018; Scullion, Gerodimos, Jackson, \& Lilleker, 2013) and also the interference of the government in public broadcasting (e.g., Hanretty, 2011). Interestingly the issue of "exclusion" seems to be present in the replies of the participants, leading to the journalists' conformity to the political elites, otherwise to her/his exclusion from the official (or unofficial) information (Rao \& Wasserman, 2015).

"Media Owners" (Table 2, Code 2.2.2.) as a pressure point was also mostly acknowledged by the Greek participants: "If you worked for a big news channel, you could of course not say, or imply, that you are in favor of the drachma and against the euro" (ParticipantGR05); and as ParticipantGR01 also stated:

My then Director was going to run for Minister under PASOK. Well, he thought that my 'line' was against PASOK, so he locked up my computer! My files! My personal archive that I have been constructing for 12 years! I had to take legal actions to have access to my personal archive!

Cypriot participants replied mostly in the line that "rarely was there direct influence by media owners. At least where I was working I had not heard the owner gave a specific 'line"' (ParticipantCY09), or that "there were some interventions, but indirectly, for example 'if we don't have ads, how are you all going to get paid.' That is, we had to satisfy those who gave us advertisements in order to keep our salary" (ParticipantCY06). Most Spanish participants felt that there could be a "line" from the 
media owners, but this was due to the fact that "in general, media adapt to its editorial line" (ParticipantSP03) or "there were certain 'recommendations' or 'indications' from the owners of the media I work in, which we could classify as 'ethically questionable.' However, these 'recommendations' were refuted and put aside from the Editorial Office and the Director of the media" (ParticipantSP07). The major difference between participants' replies is that the Greek participants witnessed a direct interference of the media owners, the Cypriot participants vaguely acknowledged "some" kind of pressure and the Spanish participants either rationalized this interference or replied that mostly these pressures (if present) did not reach them personally.

"Banks" (Table 2, Code 2.2.3.) also emerged as a pressure point, mostly and most intensely by Greek participants: "Of course, if your channel was against the Memorandum or the Government, there would be no more loans for that channel. At the end, it's all about what the banks wanted" (ParticipantGR05). The issue of "loans from the banks" as means of exerting direct or indirect influence on the journalistic message came up in most of the replies of the Greek participants. In some of the replies, "Banks" represented not only the Greek banks, as monetary institutions, but the "bankers" in general: "If you wanted your channel to survive, you had to do what the bankers wanted. Not only the banks in Greece, but the banks in Europe" (ParticipantGR06). This issue derives from the business model of the media, where, especially in Greece, the media are mostly dependent on bank loans. The responses of the Cypriot participants were mixed. The majority of the responses acknowledged a mild to strong interference of the banks, e.g.:

Since 2010-2011, banks risked going bankrupt, so advertising was scarce, real estate was frozen, as was also the case for cars, then the media had only food advertising. That is, we had a $70 \%$ reduction in advertising. So you couldn't write against the banks, as you may well understand. (ParticipantCY02)

But there were also two cases, where the participants felt no interference from the banks: "I don't think banks would tell the media what to write. That is, I have never heard of this" (ParticipantCY11). Additionally, Spanish participants did not mention any direct interference of the banks in the journalistic practice, but most of them acknowledged the power of the banks to indirectly control enterprises through loans.

\section{Conclusions}

Based on the participants' replies and experiences, concerning the implementation of the Memoranda in the European South, in particular the way anti-Memoranda voices were (self-)"silenced," three focal points emerge in relation to journalism as a profession. The first one concerns the international institutions that imposed the
Memoranda. The second one is related to working conditions in general, and the third one to the special working terms of journalists. All three focal points have, according to the respondents' answers, an impact on their perception of "being safe," not only in terms of working conditions, but as a psychological state, mostly derived from perceived (or actual) economic stressors.

The first issue concerns the source of information. According to the respondents in this study the IMF, as well as the European institutions (the EU and the European Central Bank), would use parallel information channels for specific journalists. Parallel to the official and public briefings, that were open to accredited journalists, there were mechanisms addressed selectively to journalists, providing them with privileged briefing. Thus, unequal access to information affected professionals who had no access and placed them in a disadvantaged position regarding the media organization management and the public, risking getting marginalized. Concurrently, it improved the position of those who had acceded to the closed group of the privileged and were perennially provided with feedback, exclusive information, interviews of key players at that time, etc. The criterion for such segregation was almost always political, as enhanced access to information benefited the ones who were willing to communicate the messages of the Troika uncritically to the public. On the other hand, the journalists who were excluded from privileged access to information were the ones who maintained a critical stance, asked discomforting questions, pointed out the inconsistencies of the austerity programs, reminded of the negative implications of imposing similar programs in other countries by the IMF, etc. Moreover, other forms of providing information were extensively used, such as seminars organized by the IMF in its headquarters in the USA, which were characterized as a means of "constructing" the journalists' silence and ensuring their "co-operation." Respondents highlighted similar practices used by the German Embassy in Greece, which organized trips to Germany for Greek journalists selected with non-transparent criteria. Neither the IMF nor the German Embassy ever made the list of the journalists who benefited from such seminars and trips public. The silence they held did not confirm their effort to appear as if operating in a transparent environment of open access to information.

The problem resulting from such instances of unfair influence on journalists is related to their ability to inform the public they address in the most objective and unaffected manner possible, as well as the feeling of job insecurity. The extended use of practices that were characterized as "bribes," especially by organizations such as the IMF, distorts the information and cancels a priori the philosophy, which is implicit with the profession, namely checking and confirming any news before it goes public.

Regarding working conditions in Greece, Cyprus, and Spain, the pressure put on journalists who formed our sample did not differ from the one forced on all other employees. Cuts on wages, unsolicited transformation of 
collective agreements to individual ones without the consent of the employees, dismissals, work intensification, elongation of work shifts, work during weekends and at nighttime, and working away from the office without extra compensation, unpaid internships and uninsured work, intimidation at work, were the norm in smaller or larger organizations. The media did not constitute an exception, for one more reason: The economic turmoil that shook media organizations was greater than in the rest of the economy, because the advertisements and the reading public declined sharply. The shrinkage of the mass media sector, despite its importance in the political and public life, remains undiminished and has led to a severe decrease in journalists' income, having a negative impact on their working conditions and performance as well. In such an environment, censorship from the administration offices as well as self-censorship as a means of survival bloomed.

There are, however, some aspects that make the profession of a journalist different and these refer to the degrees of (even a relative) freedom that journalists ought to have in order to properly perform their duty. The practices of the unfair influence of journalists, in this sample, by the Troika (added to practices that may exist in every country) would not have been so effective had their working terms not set the ground for such practices to flourish. Most of the participants in this study referred to incidences such as: discrimination, persecutions, even dismissals on account of journalists' opinions, arbitrary interventions to the content of reporting, even on the commentary, etc. What also functioned negatively according to the participants of this study was ideological terrorism, which in the name of "patriotic duty" expelled any critique as disputing national interests. Similar incidents, which transferred the state of emergency of the country in the journalist profession, showed the absence of a code of conduct that would govern the operation of news agencies, respected by the ownership, the administration, the employees, and anyone else who could be held accountable for it.

In the context of the above, and parallel to the new form of journalism safety that emerged from the financial crisis - the one of (self-)censorship and constructed silence-three necessities arise: The first one concerns the public accountability of international institutions for their relationship with the media and publicity. The second one is about the regulation of working relations, since it is now ascertained that the deregulation regime leads to the degradation of human labor. And the third one has to do with the closer monitoring of the code of conduct so that the right to information is respected in times when society needs it most: when, in the middle of the crisis, core values are being overthrown.

\section{Acknowledgments}

The authors would like to thank the journalists in Greece, Cyprus, and Spain who participated in this study for their trust and courage needed for the content of the interviews.

\section{Conflict of Interests}

The authors declare no conflict of interests.

\section{References}

Abramson, J. (2010). Sustaining quality journalism. Daedalus, 139(2), 39-44.

Alderman, L. (2019, February 14). Europe's middle class is shrinking: Spain bears much of the pain. The New York Times. Retrieved from https://nyti.ms/2p37Uz0

Bartholomae, S., \& Fox, J. (2017). Coping with economic stress: A test of deterioration and stress-suppressing models. Journal of Financial Therapy, 8(1), 6.

Bond, F. W., \& Bunce, D. (2001). Job control mediates change in a work reorganization intervention for stress reduction. Journal of Occupational Health Psychology, 6(4), 290-302.

Browne, T., Evangeli, M., \& Greenberg, N. (2012). Trauma-related guilt and posttraumatic stress among journalists. Journal of Traumatic Stress, 25(2), 207-210.

Carlsson, U., \& Pöyhtäri, R. (2017). The assault on journalism: Building knowledge to protect freedom of expression. Goethenburg: Nordicom.

Chalofsky, N. (2003). An emerging construct for meaningful work. Human Resource Development International, 6(1), 69-83.

Choo, A. S., Linderman, K. W., \& Schroeder, R. G. (2007). Method and psychological effects on learning behaviors and knowledge creation in quality improvement projects. Management Science, 53(3), 437-450.

Christophorou, C., \& Spyridou, L. P. (2017). Media pluralism monitor 2016: Monitoring risks for media pluralism in EU and beyond: Country report-Cyprus. Florence: Centre for Media Pluralism and Media Freedom.

Cottle, S. (2011). Media and the Arab uprisings of 2011. Journalism, 12(5), 647-659.

Dollard, M. F. (2007). Necrocapitalism: Throwing away workers in the race for global capital. In J. Houdmont \& S. McIntyre (Eds.), Occupational health psychology: European perspectives on research, education and practice (Vol. 2, pp. 169-193). Maia: ISMAI.

Duménil, G., \& Lévy, D. (2011). The crisis of neoliberalism. Cambridge, MA:Harvard University Press.

Edmondson, A. (1999). Psychological safety and learning behavior in work teams. Administrative Science Quarterly, 44(2), 350-383.

Edmondson, A. C. (2008). The competitive imperative of learning. Harvard Business Review, 86(7/8), 60.

European Commission. (2011). The economic adjustment programme for Portugal (Occasional Papers 79). Brussels: European Commission. Retrieved from https://bit.ly/2ANIrfh 
European Commission. (2012). The financial sector adjustment programme for Spain (Occasional Papers 118). Brussels: European Commission. Retrieved from https://bit.ly/2ObOzf2

European Commission. (2013). The economic adjustment programme for Cyprus (Occasional Papers 149). Brussels: European Commission. Retrieved from https:// bit.ly/2U8RwKz

European Commission's Directorate General for Economic and Financial Affairs. (2019). 18-Gross public debt. European Commission's Directorate General for Economic and Financial Affairs. Retrieved from https://ec.europa.eu/economy_finance/ameco/ user/serie/SelectSerie.cfm

European Parliament. (2013). Regulation (EU) No 472/2013 of the European Parliament and of the Council. Brussels: European Parliament. Retrieved from https://bit.ly/2RJ1CjY

European Stability Mechanism. (2018). Explainer on ESM and EFSF financial assistance for Greece. European Stability Mechanism. Retrieved from https://bit.ly/ $2 \mathrm{MrScpc}$

Feinstein, A., \& Starr, S. (2015). Civil war in Syria: The psychological effects on journalists. Journal of Aggression, Conflict and Peace Research, 7(1), 57-64.

Gratton, L., \& Erickson, T. J. (2007). Eight ways to build collaborative teams. Harvard Business Review, 85(11), 100.

Hanitzsch, T., \& Vos, T. P. (2018). Journalism beyond democracy: A new look into journalistic roles in political and everyday life. Journalism, 19(2), 146-164.

Hanretty, C. (2011). Public broadcasting and political interference. London: Routledge.

Hayes, A. F., Scheufele, D. A., \& Huge, M. E. (2006). Nonparticipation as self-censorship: Publicly observable political activity in a polarized opinion climate. Political Behavior, 28(3), 259-283.

Hellenic Statistical Authority. (2018, April 27). Survey on daily and periodical press 2017 [Press Release]. Retrieved from https://bit.ly/2uMi1Lr

losifidis, P., \& Boucas, D. (2015). Media policy and independent journalism in Greece. London: Open Society Foundations. Retrieved from https://goo.gl/Vvyvvx

Johnson, J. (2008). Globalization, workers' power and the psychosocial work environment-Is the demandcontrol-support model still useful in a neoliberal era? Scandinavian Journal Work Environment and Health, 2008(6), 15-21.

Kahn, W. A. (1990). Psychological conditions of personal engagement and disengagement at work. Academy of Management Journal, 33(4), 692-724.

Karasek, R. A. (2008). Low social control and physiological deregulation: The stress disequilibrium theory, towards a new demand-control model. Scandinavian Journal of Work Environment and Health, 34(6), 117-135.

Khondker, H. H. (2011). Role of the new media in the Arab Spring. Globalizations, 8(5), 675-679.
Kosmas, P. (2019). The Memorandum legacy: A lasting farewell to debt crises or a bitter return to the markets just until the next financial crises? Destruction tales by Cyprus, Portugal, and Greece. Paper presented at "Historical Materialism" Athens Conference, Athens, Greece.

Lapavitsas, C., Kaltenbrunner, A., Labrinidis, G., Lindo, D., Meadway, J., Michell, J., . . . Vatikiotis, L. (2012). Crisis in the Eurozone. London: Verso.

Leandros, N. (2010). Media concentration and systemic failures in Greece. International Journal of Communication, 4(2010), 886-905.

Levaot, Y., \& Mark Sinyor MSc, M. D. (2013). Trauma and psychological distress observed in journalists: A comparison of Israeli journalists and their western counterparts. The Israel Journal of Psychiatry and Related Sciences, 50(2), 118.

Madsen, P. M., \& Desai, V. (2010). Failing to learn? The effects of failure and success on organizational learning in the global orbital launch vehicle industry. Academy of Management Journal, 53(3), 451-476.

McNair, B. (2013). Trust, truth and objectivity: Sustaining quality journalism in the era of the contentgenerating user. In C. Peters \& M. J. Broersma (Eds.), Rethinking journalism (pp. 87-100). London: Routledge.

Milioni, D. L., Spyridou, L. P., \& Koumis, M. (2017). Cyprus: Behind closed (journalistic) doors. In T. Eberwein, S. Fengler, \& M. Karmasin (Eds.), The European handbook of media accountability (pp. 39-46). London: Routledge.

Milojević, A., \& Krstić, A. (2018). Hierarchy of influences on transitional journalism: Corrupting relationships between political, economic and media elites. European Journal of Communication, 33(1), 37-56.

Nembhard, I. M., \& Edmondson, A. C. (2012). Psychological safety. In G. Spreitzer \& K. Cameron (Eds.), The Oxford handbook of positive organizational scholarship (pp. 1-26). Oxford: Oxford University Press.

Nembhard, I. M., \& Tucker, A. L. (2011). Deliberate learning to improve performance in dynamic service settings: Evidence from hospital intensive care units. Organization Science, 22(4), 907-922.

Nikolaidis, A. (2017). The impact of austerity on the Greek news media and public sphere. In A. David (Ed.), The death of public knowledge? How free markets destroy the general intellect (pp. 33-59). London: Goldsmiths Press.

Osborn, M., \& Smith, J. A. (1998). The personal experience of chronic benign lower back pain: An interpretative phenomenological analysis. British Journal of Health Psychology, 3(1), 65-83.

Papathanasopoulos, S. (2005). Politics and media: The case of Southern Europe. Athens: Kastaniotis.

Probst, T. M. (2005). Economic stressors. In J. Barling, K. Kelloway, \& M. Frone (Eds.), Handbook of work stress (pp. 267-297). Thousand Oaks, CA: Sage.

Rao, S., \& Wasserman, H. (2015). A media not for all: A 
comparative analysis of journalism, democracy and exclusion in Indian and South African media. Journalism Studies, 16(5), 651-662.

Reid, K., Flowers, P., \& Larkin, M. (2005). Interpretative phenomenological analysis: An overview and methodological review. The Psychologist, 18(1), 20-23.

Salaverría, R., \& Baceiredo, B. G. (2018). Spain media landscape. Maastricht: European Journalism Centre. Retrieved from http://digitaltransmedia. digitaltransformers.cat/wp-content/uploads/2018/ 05/EJC-Media-Landscape-Spain.pdf

Scullion, R., Gerodimos, R., Jackson, D., \& Lilleker, D. (Eds.). (2013). The media, political participation and empowerment. London: Routledge.

Siemsen, E., Roth, A. V., Balasubramanian, S., \& Anand, G. (2009). The influence of psychological safety and confidence in knowledge on employee knowledge sharing. Manufacturing and Service Operations Management, 11(3), 429-447.

Smith, J. A. (1996). Beyond the divide between cognition and discourse: Using interpretative phenomenological analysis in health psychology. Psychology and Health, 11(2), 261-271.

Smith, J. A., Jarman, M., \& Osborn, M. (1999). Doing interpretative phenomenological analysis. In M. Murray \& K. Chamberlain (Eds.), Qualitative health psychology: Theories and methods (pp. 218-240). London, Thousand Oaks, CA, and New Delhi: Sage.

Spyridou, L. O. (2015). Producing protest news. The
Cyprus Review, 27(1), 98-99.

Tsai, F. J., \& Chan, C. C. (2011). The impact of the 2008 financial crisis on psychological work stress among financial workers and lawyers. International Archives of Occupational and Environmental Health, 84(4), 445-452.

Villanueva, J., \& Vega, G. A. M. (2019, March 28). Spain's broken social elevator: How the crisis damaged upward mobility. El País. Retrieved from https://bit.ly/ 2osGUZF

Viseu, J., Leal, R., de Jesus, S. N., Pinto, P., Pechorro, P., \& Greenglass, E. (2018). Relationship between economic stress factors and stress, anxiety, and depression: Moderating role of social support. Psychiatry Research, 268, 102-107.

Vogiatzoglou, M. (2016). Cyprus explosion: Financial crisis and anti-austerity mobilization. In D. della Porta, M. Andretta, T. Fernandes, F. O'Conner, E. Romanos, \& M. Vogiatzoglou (Eds), Late neoliberalism and its discontents in the economic crisis: Comparing social movements in the European periphery (pp. 243-259). Cham: Palgrave Macmillan.

Whelan, C. T., Russell, H., \& Maître, B. (2016). Economic stress and the Great Recession in Ireland: Polarization, individualization or 'middle class squeeze'? Social Indicators Research, 126(2), 503-526.

Wolfgang, J. D., Vos, T. P., \& Kelling, K. (2019). Journalism's relationship to democracy: Roles, attitudes, and practices. Journalism Studies, 20(14), 1977-1994.

\section{About the Authors}

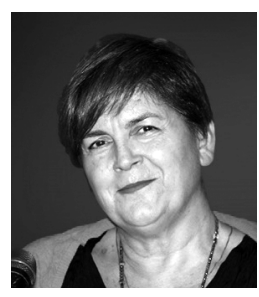

Sofia Iordanidou is an Associate Professor of Journalism and Communication at the Open University of Cyprus (OUC) and the Chair of the Advanced Media Institute, Applied Research in Communication and Journalism. Since 2011, the MA “Communication and New Journalism" program has been developed and is being offered at the OUC under her responsibility. She is the publisher of the Dimosiografia journal and the website manager of www.dimosiografia.com

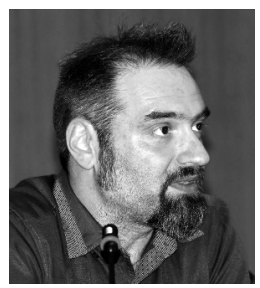

Emmanouil Takas holds a PhD in Social Psychology from Panteion University, Greece, and is the Coordinator of Research pillar at the Advanced Media Institute. His research interests include strategic communication, processes of social influence, framing and social representations. He teaches Social and Political Psychology, Qualitative and Quantitative Research Methods, and Media Psychology at City Unity College in Athens, Greece.

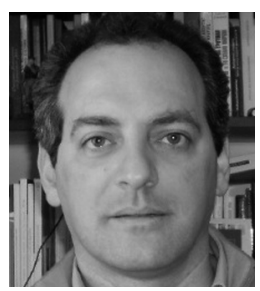

Leonidas Vatikiotis is a Statistics Science graduate. His doctoral dissertation was on the field of Political Economy. Since 1991, he's been working as a journalist-analyst, specializing in macroeconomic and foreign affairs issues. Since 2017, he is the Editor in Chief of the Dimosiografia journal, published by the Advanced Media Institute under the auspices of the MA Program "Communication and New Journalism" of the Open University of Cyprus, where he also teaches. He has also served as scientific editor for important documentary films. 


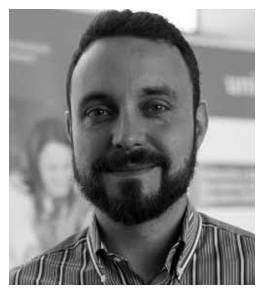

Pedro García is a Science Information graduate with a Spanish Literature Master and Ph.D. in Spanish Language and Hispanic Literature at the Universidad Complutense de Madrid. His research career has always been marked by an interdisciplinary perspective. His work explores the connections between Literature and Gender. From 2016, he combines his research activity with teaching in Universidad Internacional de La Rioja. 